\title{
DIVERSITY OF ALGAE IN RELATION TO WATER POLLUTION OF SATRI TANK CHHATARPUR (M.P.) INDIA
}

\author{
Pushpendra Kumar Khare \\ P.G. Department of Botany \\ Govertment Maharaja Autonomous College \\ Chhatarpur (M.P.) 471001 India
}

\begin{abstract}
This paper is report of phytoplankton from Satri Tank of Bundelkhand region, India. Total 43 species and 27 genera have been identified from Satri Tank, among these 18 species belonged to Chlorophyceae, 17 species to Cyanophyceae, 6 to Bacillariophyceae and 2 to Euglenophyceae. Qualitatively Chlorophyceae were dominant while quantitatively Cyanophyceae were abundant. The species of Spirulina, Oscillatoria, Microcystis and Nostoc were dominant. The tank is indicative of highly eutrophic status and biologically dead in term of its unability to provide the aesthetic pleasure of swimming, boating and fishing.
\end{abstract}

Key words: Lower plant, Phytoplankton, Eutrophic.

\section{INTRODUCTION}

Satri Tank situated in latitude $26^{\circ} 6^{\prime}$ and $25^{\circ} 20^{\prime}$ north and meridians of longitude $78^{\circ} 59^{\prime}$ and $80^{\circ} 26^{\prime}$ east. It was built in 1933 and is popular for fish farming under the special program of fishries development "CRASH" and now facing the problem of organic pollution due to major discharge of raw sewage, detergents, excremental matter and also receives wastes from adjoining human settlements. Tank has an average maximum depth $1.2 \mathrm{~m}$ and emanates foul smell in summer season due to effluent accumulation there by causing health hazards to the surrounding human population.

\section{MATERIALS AND METHODS}

Water samples were collected twice in a month of year 1999. They were analysed for physicochemical and biological parameters (Adoni 1985,
Trivedi and Goel 1986, Michael 1973). Plankton samples were collected by standard methods from predetermined sampling sites and preserved in $2.5 \%$ formalein and few drops of glycerine. Counting and identification of plankton were done as per APHA (1985).

\section{RESULTS AND DISCUSSION}

Phytoplankton population was mainly represented by chlorophyceae, cyanophyceae, Bacillariophyceae while members belonging to euglenophyceae were sparsely represented. A total number of 43 species belonging to 27 genera were identified. Cyanophyceae was represented by 17 species $(39.28 \%$ of total phytoplanktons species) while chlorophyceae exhibited $27.96 \%$ of total phytoplanktons. Bacillariophyceae represented 6 species and euglenophyceae represented only two species (Figs. 1, 2, Table 1). 


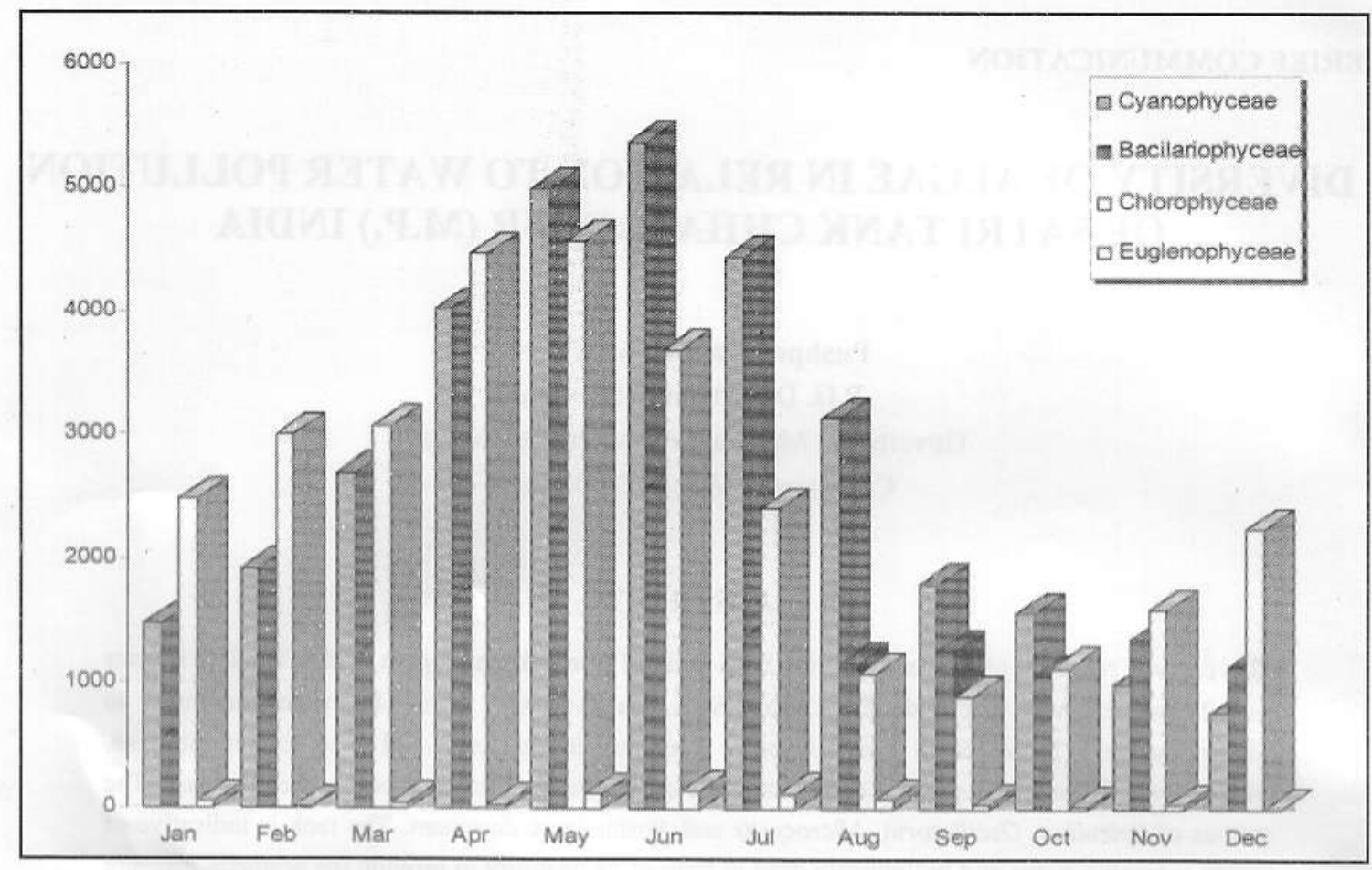

Fig. 1. Seasonal variation of phytoplankton (Org./l) in Satri Tank, Chhatarpur (M.P.) from January to December 1999.

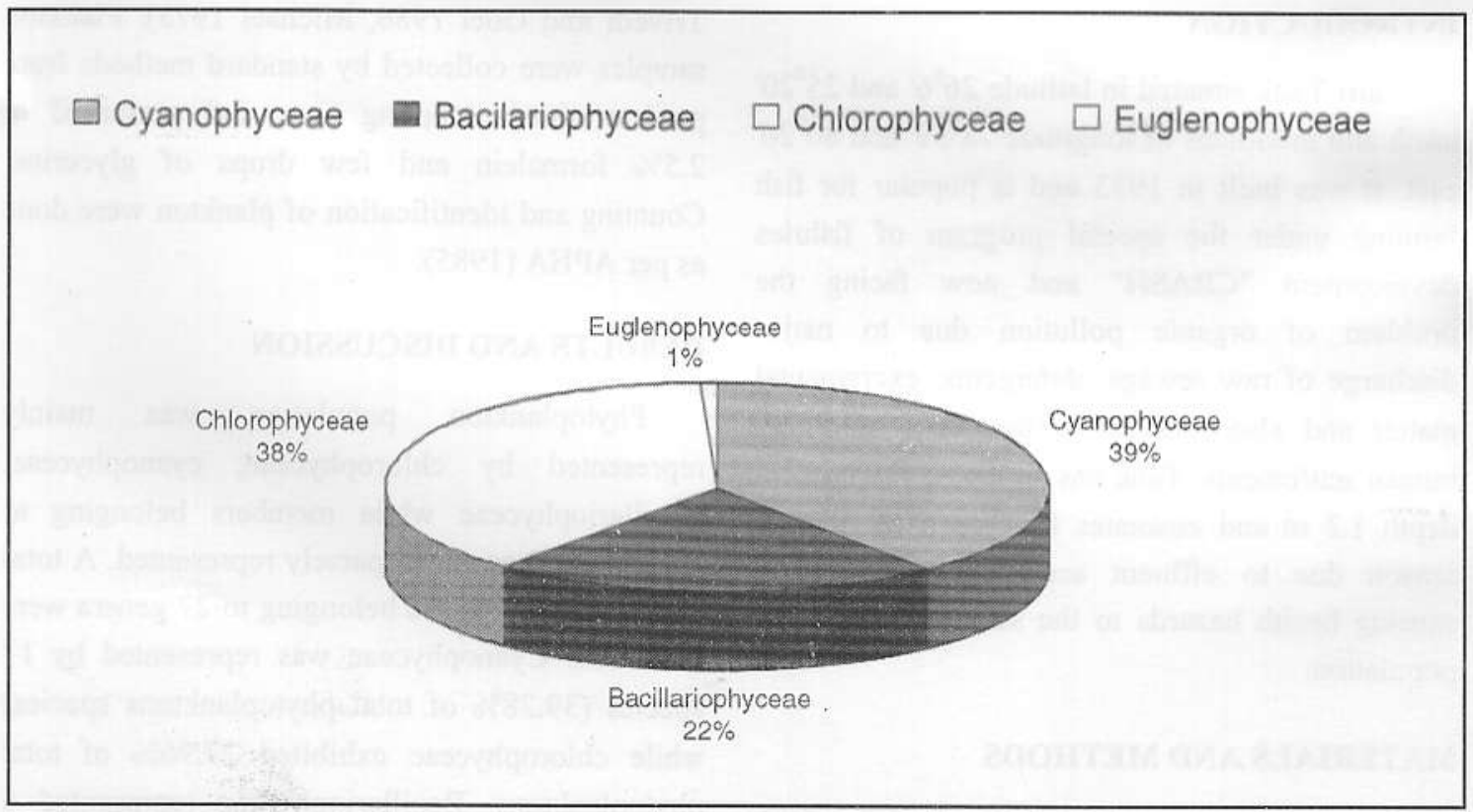

Fig. 2. Average composition (\%) of phytoplankton's in Satri Tank, Chhatarpur (M.P.) India during January to December 1999. 
Table 1. Number of different algal groups in the Satri tank, Chhatarpur.

\begin{tabular}{llcc}
\hline Class & Order & Genera & Species \\
\hline Chlorophyceae & Volvocales & 1 & 1 \\
& Chlorococcales & 4 & 8 \\
& Conjugales & 3 & 4 \\
& Desmidiales & 3 & 5 \\
Euglenophyceae & & 1 & 2 \\
Bacillariophyceae & & 6 & 6 \\
Cyanophyceae & Chroococeales & 1 & 2 \\
& Nostocales & 8 & 15 \\
& & 27 & 43 \\
\hline
\end{tabular}

The number of species belonging to a total of 27 genera recorded and the size of the respective population varied according to seasons as well as sites. Chlorophyceae was the dominant class with 18 species. It was followed by cyanophyceae having 17 species while bacillariophyceae and euglenophyceae having 6 and 2 species, respectively. Among the chlorophyceae, the most dominant group was cholrococcales comprised 8 species. Next to chlorococcales was desmidales represented by 5 species. The other orders in the descending series, conjugales (4) and volvocales (1).

Through the bacillariophyceae were represented by smaller number of species as compared to chlorophyceae and cyanophyceae, yet they dominated sufficiently in a large number round the year (Table 2) chlorophyceae ranked second when total number of individuals had been taken into accound, followed by cyanophyceae and euglenophyceae.
The most dominant species recorded from cyanophyceae were: Spirulina, Oscillatoria Microcystis sp., while from chlorophyceae, Eudorina, Pandorina, Scenedesmus, Cosmarium, Closterium and Pediastrum.

The presence of Closterium, Cosmarium and Pediastrum shows that the nature of tank is mesotrophic but the dominance of Eudorina, Pandorina and Scenedesmus sp. indicates eutrophic nature (Khare 1999). Scenedesmus sp. gives an idea about eutrophic water body. Pandorina sp. indicate pollution and eutrophication (Mittal and Sengar 1991). In this study dominant algae indicates that Satri Tank is eutrophic. The dominancy of Spirulina and Microcystus sp. in the tank are categorised as highly eutrophic.

Hutchinson (1967) reported that Melosira and Fragilaria indicate oligotrophic nature of waterbody but Navicula is usually found in alkaline water. Rawson (1956) said that eutrophic lakes characterised by diatomaceae. In present investigation on the basis of diatomaceae these tank come under meso-eutrophic status.

On the basis of these results Satri Tank is catagorised highly eutrophic in the presence of dominant cyanophycean member such as Spirulina, Microcystis, Oscillatoria and dominant chlophrophycean member Eudorina, Pandorina and Scenedesmus sp.

Table 2. Seasonal variation of phytoplanktons (orga./l) in Satri Tank Chhatarpur (M.P.) India. Figures in parentheses represent percent composition of total phytoplanktons.

\begin{tabular}{lcccccccccccc}
\hline Genus & Jan & Feb & Mar & Apr & May & Jun & Jul & Aug & Sept & Oct & Nov & Dec \\
\hline Cynophyceae & 1465 & 1917 & 2696 & 4019 & 4986 & 5362 & 4450 & 3134 & 1793 & 1553 & 996 & 783 \\
& $(32.04)$ & $(33.36)$ & $(38.34)$ & $(39.4)$ & $(38.89)$ & $(45.49)$ & $(53.15)$ & $(57.44)$ & $(44.84)$ & $(41.08)$ & $(25.03)$ & $(18.68)$ \\
Bacilariophyceae & 562 & 804 & 1216 & 1669 & 2236 & 2584 & 1375 & 1160 & 1258 & 1064 & 1351 & 1143 \\
& $(12.29)$ & $(13.99)$ & $(17.29)$ & $(16.36)$ & $(17.44)$ & $(21.92)$ & $(16.42)$ & $(21.26)$ & $(31.46)$ & $(28.14)$ & $(33.95)$ & $(27.27)$ \\
Chlorophyceae & 2484 & 3004 & 3067 & 4473 & 4574 & 3690 & 2414 & 1078 & 903 & 1130 & 1587 & 2252 \\
& $(54.34)$ & $(52.28)$ & $(43.62)$ & $(43.86)$ & $(35.37)$ & $(31.3)$ & $(28.83)$ & $(19.75)$ & $(22.58)$ & $(29.89)$ & $(39.88)$ & $(53.74)$ \\
Euglenophyceae & 60 & 20 & 52 & 37 & 124 & 151 & 134 & 84 & 44 & 35 & 45 & 12 \\
& $(1.31)$ & $(0.35)$ & $(0.74)$ & $(0.36)$ & $(0.96)$ & $(1.28)$ & $(1.60)$ & $(1.54)$ & $(1.10)$ & $(0.87)$ & $(1.13)$ & $(0.28)$ \\
Phytoplanktons & 4571 & 5745 & 7031 & 10198 & 12820 & 11787 & 8373 & 5456 & 3998 & 3780 & 3979 & 4190 \\
\hline
\end{tabular}




\section{ACKNOWLEDGEMENTS}

Author is grateful to Dr. L.C. Chourasia, Prof. and Head, Department of Botany for providing all facilities and valuable suggestions. Thanks to Dr. G.P. Rajore, Principal of Maharaja College, Chhatarpur for constant encouragement. The financial assistance given by UGC for minor research project is thankfully acknowledged.

\section{REFERENCES}

Adoni, A.D. 1985. Workbook on Limnology. Pratibha Publication, Sagar (M.P.) 212 pp.

APHA. 1985. Standard Methods for the Examination of Water and Waste Water. 16th edition, Washington.

Bajpai, A.K. and M.S. Agarkar. 1997. Lower plants at high altitude's, I some Plankton from Auli Skiing field. Ecology Environment and Conservation. 3(2):97-100.

Kumar, A. and R.N.P. Singh. 1998. Biodiversity and pollution status of Masanjore reservoirs (south Bihar) in relation to abiotic factor. $J$.
Economic Environment and Conservation. 4:139-144.

Khare, P.K. 1999. Phytoplankton as indicator of water quality and pollution status of Jagat Sagar Pond, Chhatarpur (M.P.). Geobios New Reports. 18:107-110.

Michael, R.L. 1973. Guide to the Study of Fresh Water Organisms. Department of Biological Sciences, Madurai University, Madurai, India.

Mittal, M.A. and R.H.S. Sengar. 1991. Studies on the distribution of algal flora in polluted regions of Karnara river of Agra (India). Current Trends in Limnology. 1:221-230.

Rawson, D.S. 1956. Algal indicators of tropic lake types of Sasketchwan (Canada) limnology. Ocenogra. 1:18-25.

Trivedi, R.K. and P.K. Goel. 1986. Chemical and Biological Methods for Water Pollution Studies. Environmental Publication, Karad, India. 